\title{
Minute Times Microgram Per Milliliter Per Milligram Per Gram
}

National Cancer Institute

\section{Source}

National Cancer Institute. Minute Times Microgram Per Milliliter Per Milligram Per Gram.

NCI Thesaurus. Code C117956.

Minute times microgram per milliliter, divided by milligram per gram. 